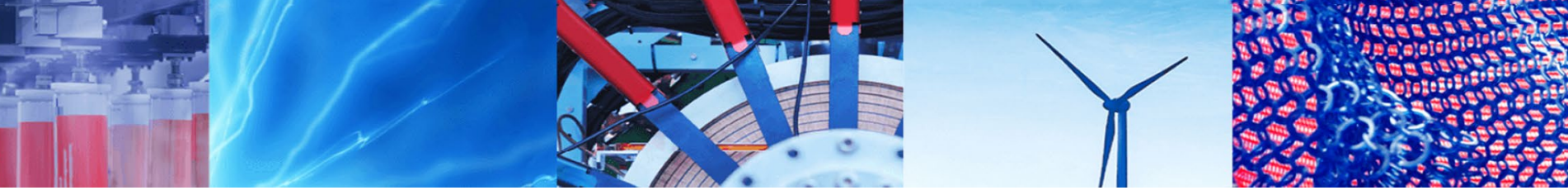

Research Article

\title{
Batch mode for adsorption of crystal violet by cedar cone forest waste
}

\author{
Meriem Zamouche $^{1}$ (D) $\cdot$ Asma Habib $^{2} \cdot$ Kenza Saaidia $^{2} \cdot$ Mossaab Bencheikh Lehocine $^{1}$
}

Received: 24 October 2019 / Accepted: 6 January 2020 / Published online: 11 January 2020

(c) Springer Nature Switzerland AG 2020

\begin{abstract}
In this work, cedar cone (CC), an abundant agricultural waste in north Algeria, was used as an adsorbent in batch mode for elimination of cationic dye crystal violet (CV) from aqueous solution. The functional groups were determined by Fourier transform infrared spectroscopy. The adsorption process was examined as the functions of adsorbent dose, contact time, initial $\mathrm{CV}$ concentration and solution $\mathrm{pH}$. The isotherms adsorption were studied at different temperatures (289-318) K, the shape obtained was compatible with the "L-type" isotherm. The equilibrium data were fitted by Langmuir and Freundlich models, using non-linear regression method. The results show that equilibrium data were best fitted by Freundlich model, with good coefficient of correlation $\left(R^{2}=0.991\right)$. The adsorption processes could be described by the pseudo-second order kinetic model with $\mathrm{R}^{2} \geq 0.997$. The results proved that CC could be a potential abundant adsorbent for the removal of $\mathrm{CV}$ from aqueous solution.
\end{abstract}

Keywords Cedar cone (CC) · Crystal violet · Adsorption · Isotherm

\section{Introduction}

We live in a world where everything is colourful including our clothes, foods, cosmetics and pharmaceutical drugs, etc. [1]. The production of synthetic dyes is increasing, because of ease of synthesis, speed of production and the wide variety of colours available compared to natural dyes [1]. Shukat et al. [2] have mentioned that more than 100,000 dyes, are synthesized with 700,000 metric tons production annually.

Synthetic dyes have a diversified chemical structure, that stems from the diversity of the chromophore groups that compose them (azo groups, anthraquinone, triarylmethane and phthalocyanine) and the diversity of application techniques (reactive, direct, dispersed and vat coloration) [1].

Due to their complex chemical structure, some of these dyes are stable to light and oxidizing agents, possess a high resistance to biodegradation and persist a long time in the environment $[3,4]$.

During the colouring process, dyes are absorbed by the product; a certain amount will end-up in the wastewater. This can cause serious environmental problems [5]. The release in the environment of synthetic dyes by various industries, mainly the textile industry, can contaminate the receiving environment. Since, these compounds are generally carcinogenic or toxic for humans. Even a low concentration, these colouring agents are highly visible and can be toxic to the aquatic environment $[3,6]$. In addition, even if the colouring molecules themselves are not necessarily originally toxic, their derivatives from biodegradation processes may become toxic [1].

Among many classes of synthetic dyes, triphenylmethane class of dyes is most versatile due to their diverse applications [2]. Crystal violet (CV) dye is a synthetic cationic dye and transmits violet colour in aqueous solution [7]. It is also known as Gentian Violet, Basic

\footnotetext{
$\triangle$ Meriem Zamouche, zamouche_meriem@yahoo.fr | ${ }^{1}$ Laboratory of the Engineering and the Processes of Environment (LIPE), Faculty of Processes Engineering, University of Constantine 3, 25000 El Khroub, Constantine, Algeria. ${ }^{2}$ Faculty of Processes Engineering, University of Constantine 3, 25000 El Khroub, Constantine, Algeria.
} 
Violet 3 and methyl violet 10B, from Rosanilines group, which is part of the Triphenylmethanes. It is a mixture of 5 and 6-methyl hydrochloride hydrides. (Penta methyl para rosaniline and hexamethyl violet), It is soluble in water, and in alcohol $[2,5,8]$.

Crystal violet is used in textile industry, paint and printing ink industry. In the medical community, it is used as a biological stain and is the active ingredient in Gram's stain. In animal husbandry and veterinary medicine, it is employed as a bacteriostatic agent veterinary and poultry feed, as well as biotechnology biological studies etc $[2,9]$.

$\mathrm{CV}$ is toxic, mutagenic, carcinogenic and poisonous to mitotic division process. It can be absorbed through the skin, causing irritation; it is harmful by inhalation and ingestion. In extreme cases, it has been reported severe kidney failure in repose to exposure to CV. It is highly toxic to mammalian cells; it is also non-biodegradable and persists in the environment for longer time. It is therefore very important to remove this dye from water and wastewater $[2,10]$.

Different techniques of treatment have been used to remove pollution by dyes from release, whether physicochemical, chemical or biological treatments such as flocculation-coagulation, precipitation, adsorption, membrane filtration, electrochemical techniques and ozonation. Advanced oxidation processes (AOP) are among the recent techniques that have been used for the oxidation of compounds difficult to degrade by traditional physicochemical and biological methods [11]. However, the AOPs relies on the uses of strong oxidant such as the $\mathrm{OH}^{*}$ radical, produced by different reactions and based on the use of more or less expensive chemical reagents. The orientation towards a less expensive treatment technique such as adsorption has been an attractive solution. Adsorption is a simple design technique and less expensive compared to other treatment techniques, especially if the adsorbent is a natural waste available in nature in abundance. This technique has shown great efficiency in the purification of waters contaminated by dyes even at high concentrations [12].

Various studies have focused on the use of inexpensive materials that are readily available for use as adsorbents, for elimination of CV dye from aqueous solution. For examples, Rice husk [9], pyrophyllite [13], Mangrove plant (Sonneratia apetala) leaf powder (MPLP), Mangrove plant (Sonneratia apetala) fruit powder (MPFP), Mango (Mangifera indica) leaf powder (MLP), Tamarind (Tamarindus indica) fruit shell powder (TFSP), Teak tree (Tectona grandis) bark powder (TTBP), Almond tree (Terminialia cattapa) bark powder (ATBP) [14]. Potato peels [15], clay [16], Kaolin [17], Mango stone biocomposite [2] and coffee husks [18] showed promising efficiencies for $\mathrm{CV}$ adsorption.
Therefore, the aims of this work, is to explore the aptitude of an abundant low-cost naturel adsorbent, cedar cone (CC), for elimination of crystal violet (CV) from aqueous solutions. The use of alternative of activated carbon, which is very expensive. In this study, the effects of adsorbent such as sorbent dosage, contact time, initial dye concentration and solution $\mathrm{pH}$ were evaluated. Isotherms adsorption were constructed at different temperatures (298-328 K) and the equilibrium data were fitted by the Langmuir and Freundlich model.

\section{Materials and method}

\subsection{Adsorbat}

Crystal violet, structure given in Fig. 1, was purchased from RAL Diagnostics; it was used without further purification. A stock solution of the dye containing $0.5 \mathrm{~g} / \mathrm{L}$ was prepared by dissolving the required amount of dye in distilled water. Solution for adsorption experiments study were prepared from the stock solution by appropriate dilution.

The dye concentration was measured in the UV spectrophotometer at the wavelength of $590.5 \mathrm{~nm}$, the spectrum absorption of $\mathrm{CV}$ is shown in Fig. 2. The aqueous solution of $\mathrm{CV}$ had a pH of 5.55, and for the study of pH effect, the solution dye $\mathrm{pH}$ was adjusted by using hydrochloric acid or sodium hydroxide solution at $0.1 \mathrm{~mol} / \mathrm{L}$. The important properties of the CV are summarized in Table 1.

\subsection{Adsorbent}

Cedar is a genus of conifer of the Pinaceae family, native to the Middle East, North Africa and Himalayas, including majestic species of trees $25-50 \mathrm{~m}$ tall. Female cedar

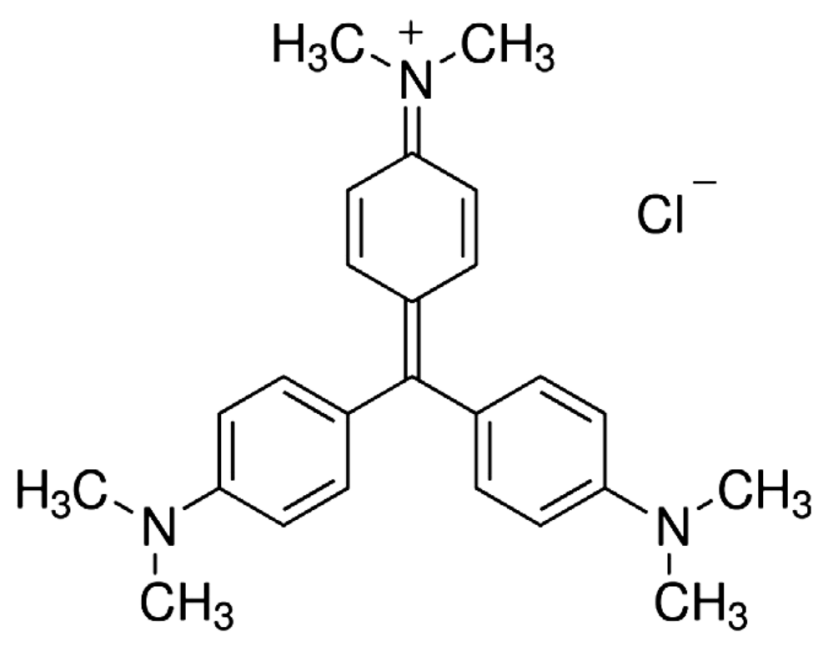

Fig. 1 Chemical structure of CV [3] 


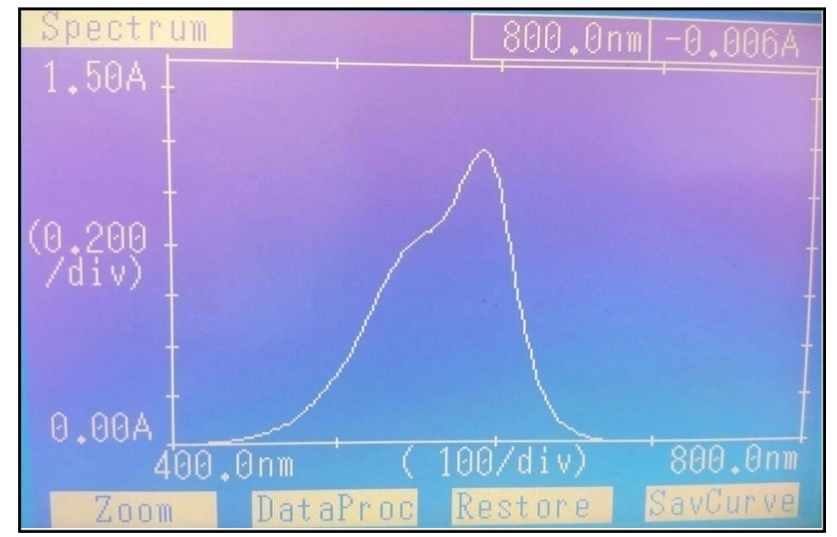

Fig. 2 Absorption spectrum of CV

Table 1 Physicochemical properties of crystal violet [3, 19]

\begin{tabular}{ll}
\hline Brute formula & $\mathrm{C}_{25} \mathrm{H}_{30} \mathrm{~N}_{3} \mathrm{Cl}$ \\
CAS number & $548-62-9$ \\
Cl Classification number & 42555 \\
Molar mass & $407.98 \mathrm{~g} / \mathrm{mol}$ \\
Solubility & $4 \mathrm{~g} / \mathrm{L}($ water, $298 \mathrm{~K})$ \\
Wavelength & $590.5 \mathrm{~nm}$ \\
\hline
\end{tabular}

cones (CC) are oblong ovoid, $6-11 \mathrm{~cm}$ in long and 4-6 cm in diameter, they are erect towards the sky and thin scales are detached before the fall of the cone; the triangular seeds are winged. Cedar cones (Fig. 3 ) is available in large quantities in northern Algeria. It was collected from the Chelia forest in Khenchla, Algeria. Cedar cones were sun dried for 5 days to reduce the moisture, crushed and sieved to obtain an average particle size between 1 and $1.25 \mathrm{~mm}$. After that, the crushed cedar cones were extensively washed with distilled water until complete elimination of color and impurities. Then, it were dried in an oven (Mamert, Allemagne) at a temperature of $378 \mathrm{~K}$ until constant weight.

\subsection{Batch adsorption study}

The adsorption experiments of CV by CC were carried out in a batch reactor perfectly agitated and thermostated, the batch system consist to mix a fixed adsorbent mass with $100 \mathrm{~mL}$ of aqueous dye solution at concentration of $50 \mathrm{mg} / \mathrm{L}$. The mixture was stirring by stirrer (IKA Heidolph, EUROSTAR digital, France) at $300 \mathrm{rpm}$ in thermostatic water bath (KOTTERMANN, France) at $298 \mathrm{~K}$ until equilibrium is reached. At appropriate time intervals, $3 \mathrm{ml}$ of mixture solution was withdrawn and centrifuged (sigma $1-6 \mathrm{P}$, France) at $3000 \mathrm{rpm}$ for $5 \mathrm{~min}$ and the dye remaining
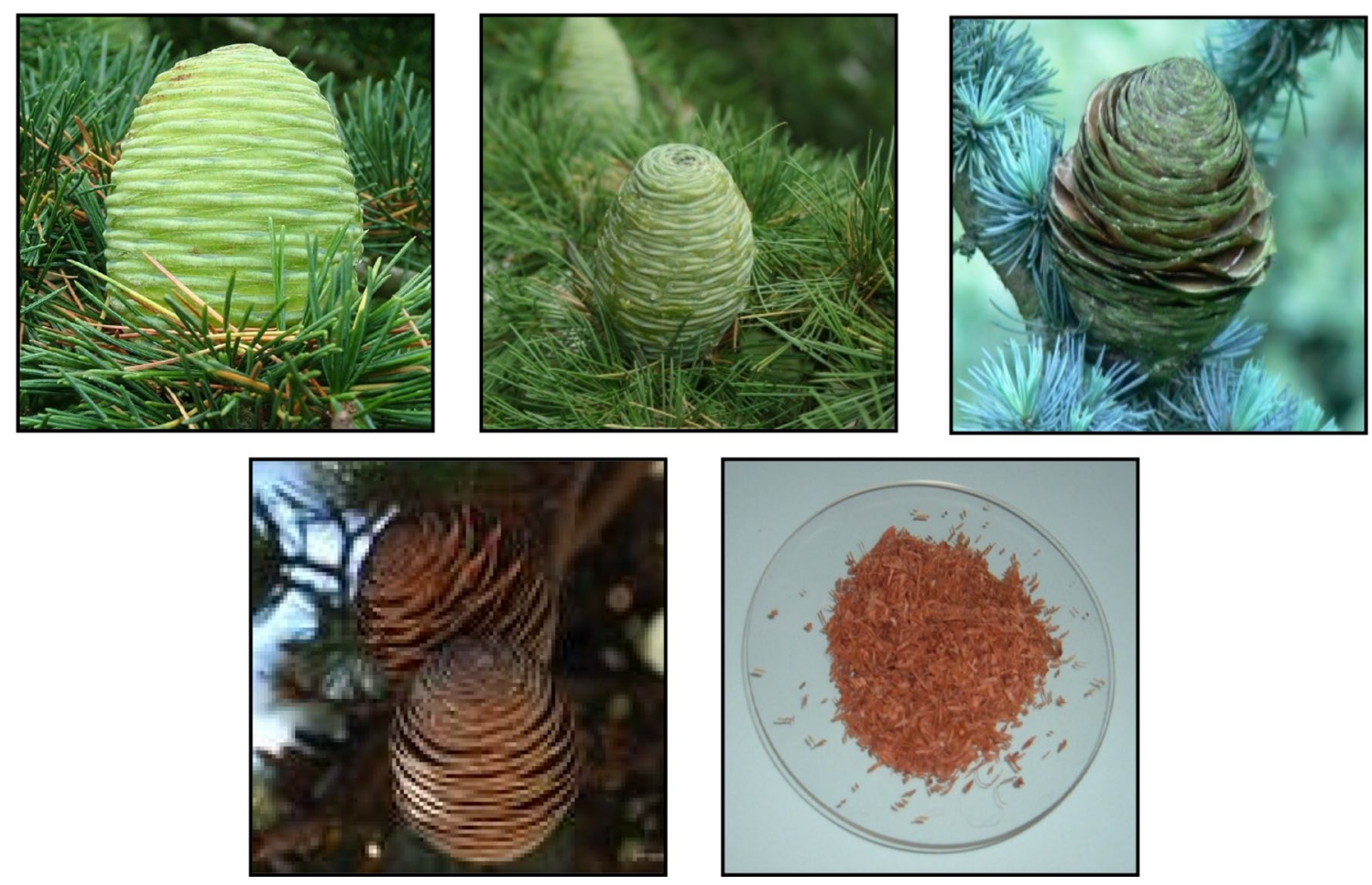

Fig. 3 Different states of cedar cones 
unadsorbed in the supernatant liquid was determined using spectrophotometer (SHIMADZUUV-1601, Germany). To study the effect of adsorbent dose, various mass of cedar cone (0.2-4 g) was adding into a series of backer's flasks, each containing $100 \mathrm{~mL}$ of crystal violet dye solution with initial concentration of $50 \mathrm{mg} / \mathrm{L}$. The adsorption isotherm study was conducted at three different temperatures (298, 308 and $318 \mathrm{~K}$ ) for the dye concentration (10-200 mg/L). The amount of dye adsorbed per unit mass of the adsorbent is calculated from the residual concentration in solution according to the following equation:

$q_{t}=\frac{C_{0}-C_{t}}{m} * V$

where $\mathrm{q}_{\mathrm{t}}$ : amount of pollutant per unit mass at $\mathrm{t}$ time $(\mathrm{mg} / \mathrm{L}) ; C_{0}$ : initial concentration $(\mathrm{mg} / \mathrm{L}) ; C_{\mathrm{t}}$ : residual concentration at time (mg/L); $\mathrm{V}$ : volume of solution ( $\mathrm{L}) ; \mathrm{m}$ : mass of the adsorbent $(\mathrm{g})$.

The percent removal of dye $E(\%)$ is computed from the following expression:

$E(\%)=\frac{C_{0}-C_{f}}{C_{0}} * 100$

\section{Results and discussion}

\subsection{The FTIR analysis of cedar cone}

In order to identify the functional groups present on the surface of cedar cone surface, we have analysis the adsorbent by Fourier transforms infrared (FTIR) spectroscopy (Agilent technology Cary 600 FTIR spectrometer), the FTIR spectral range is from 400 to $4000 \mathrm{~cm}^{-1}$.

The FTIR spectrum (Fig. 4) shown many bands; reflecting the complex nature of the adsorbent. The bands at about $464.8 \mathrm{~cm}^{-1}$ can could be assigned to the stretching of $C-C$, the pics at $1028.0 \mathrm{~cm}^{-1}$ can be attributed to the $\mathrm{C}-\mathrm{O}-\mathrm{C}$ elongation. The bonds observed at $1382.9 \mathrm{~cm}^{-1}$ could be assigned to asymmetric band of $\mathrm{CH}_{3}$ or $\mathrm{C}-\left(\mathrm{CH}_{3}\right)_{2}$ [20], since the pic observed at $1514.0 \mathrm{~cm}^{-1}$ is attributed to the deformation of $\mathrm{N}-\mathrm{H}$ to nitro aromatic compounded. The bands observed at $1627.8 \mathrm{~cm}^{-1}, 2366.5 \mathrm{~cm}^{-1}, 2856.4 \mathrm{~cm}^{-1}$ can be assigned to the elongation of $\mathrm{C}=\mathrm{C},-\mathrm{C} \equiv \mathrm{N}-,-\mathrm{C} \equiv \mathrm{N}$ - respectively. The bands between 2856.4 and $2923.9 \mathrm{~cm}^{-1}$ could be assigned to the aliphatic $\mathrm{C}-\mathrm{H}$ groups. Two other pics have been observed at $3417.6 \mathrm{~cm}^{-1}$ and $3759.0 \mathrm{~cm}^{-1}$, indicates the presence of $\mathrm{OH}$ group which can be attributed to the water adsorbed on the CC surface [21,22].

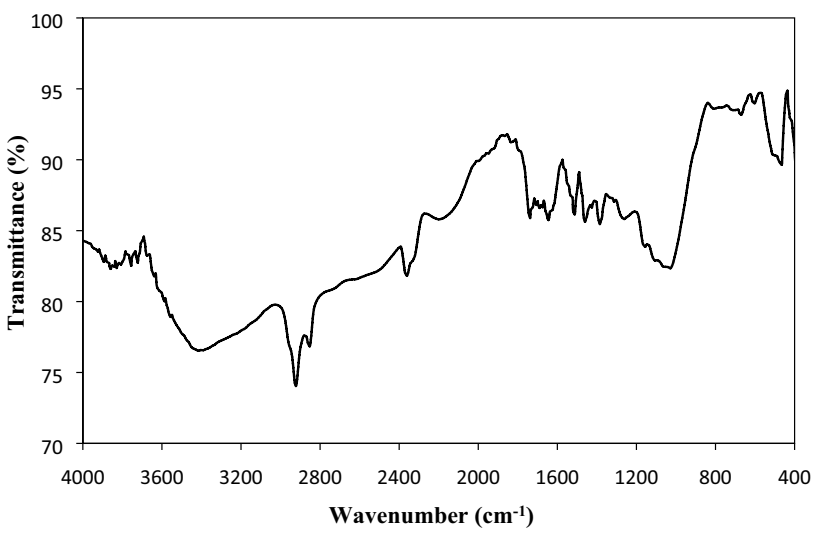

Fig. 4 FTIR transmission spectra of cedar cones

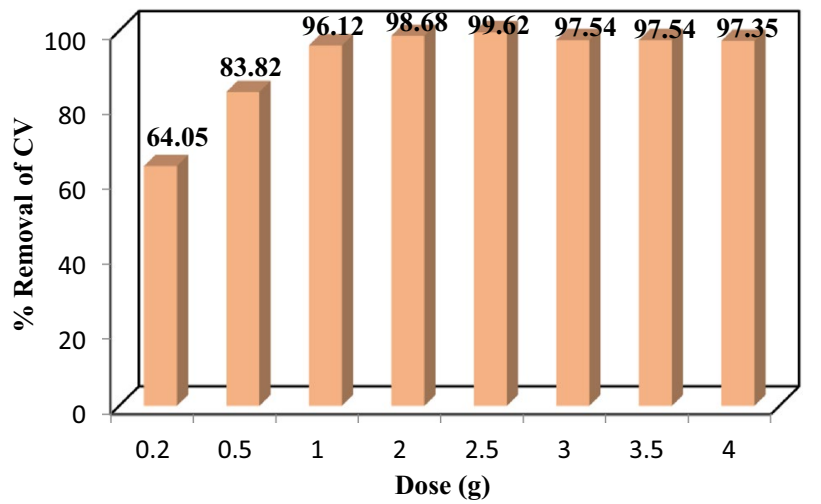

Fig. 5 The percent removal of $\mathrm{CV}$ by $\mathrm{CC}$ as function of adsorbent dose $\left(C_{0}=50 \mathrm{mg} / \mathrm{L}, \mathrm{W}=300 \mathrm{tr} / \mathrm{min}\right.$, and $\left.\mathrm{T}=298 \mathrm{~K}\right)$

\subsection{Effect of sorbent dose and contact time}

To investigate the influence of adsorbent mass on dye adsorption, experiments were conducted at an initial $\mathrm{CV}$ concentration of $50 \mathrm{mg} / \mathrm{L}$, while the adsorbent mass was varied from 0.2 to $4 \mathrm{~g}$ and the other parameters are kept constant. Figure 5 shows the effect of the adsorbent dose on the percent removal of CV. It has been observed that the percent removal of CV depends on the dose of cedar cone. It increased rapidly with increasing CC dose up to $1 \mathrm{~g}$, and then remained almost unchanged between 1 and $4 \mathrm{~g}$ from 96.12 to $97.35 \%$ (Fig. 5). The highest percentage of elimination observed is $99.62 \%$, almost a total elimination for a dose of $2.5 \mathrm{~g}$. This mass was chosen as the optimal mass. The increase in the percent removal of CV is explained by the increase of the available adsorption surface sites.

The effect of contact time on CV removal by CC showed more or less rapid adsorption of the dye during the first $90 \mathrm{~min}$ as the adsorbent dose increased from 0.2 


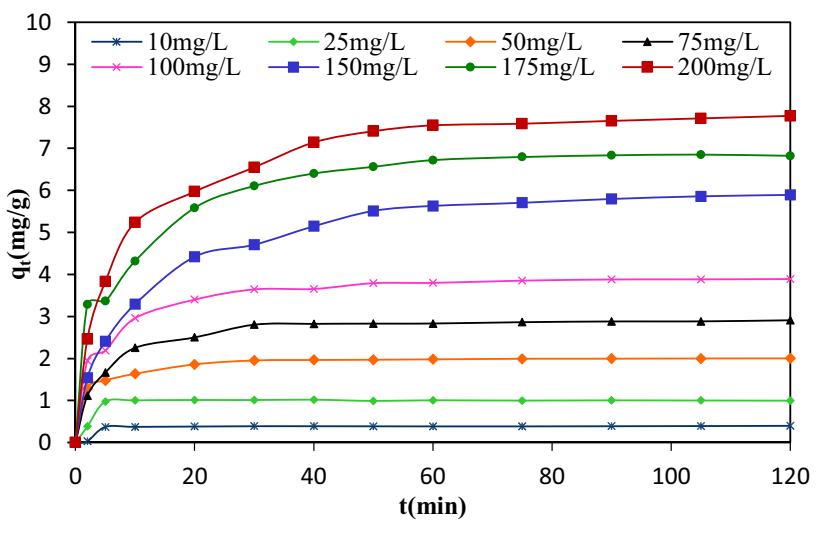

Fig. 6 Effect of initial concentration of dye on the removal of CV by $\mathrm{CC}(\mathrm{m}=2.5 \mathrm{~g}, \mathrm{~W}=300 \mathrm{rpm}, \mathrm{T}=298 \mathrm{~K})$

to $1 \mathrm{~g}$. The equilibrium time decrease from $30 \mathrm{~min}$ until reach $5 \mathrm{~min}$ when the dose of adsorbent passed from 1 to $4 \mathrm{~g}$. A faster equilibrium time, indicate a high degree of affinity between the dye and the adsorbent.

\subsection{Effect of initial dye concentration}

The effect of initial dye concentration on CV adsorption by CCs was studied by varying the initial concentration as follows 10, 25, 50, 75, 100, 175 and $200 \mathrm{mg} / \mathrm{L}$. Figure 6 illustrates the adsorption of CV for different initial concentrations of dye at $298 \mathrm{~K}$ as function of contact time. Figure 6 show that the amount adsorbed increased with the increase in the concentration of dye. When the initial $\mathrm{CV}$ concentration was increased from 50 to $200 \mathrm{mg} / \mathrm{L}$, the adsorption uptake of CC increased from 0.39 to $7.7 \mathrm{mg} / \mathrm{g}$. The increase in the initial dye concentration causes an increase in the driving force, which leads to the weakness of all the resistances of the dye between the aqueous and solid phases, which results in an increase of adsorption [23].

\subsection{Effect of solution $\mathrm{pH}$}

To study the effect of solution $\mathrm{pH}$ on the adsorption of CV, the $\mathrm{pH}$ was adjusted by adding $\mathrm{NaOH}$ or $\mathrm{HCl}$ at $0.1 \mathrm{~mol} / \mathrm{L}$. The effect of $\mathrm{pH}$ solution was study at the optimum adsorbent masse $(2.5 \mathrm{~g})$ and at stirring speed of $300 \mathrm{rpm}$ with $50 \mathrm{mg} / \mathrm{L}$ initial concentration of dye. The $\mathrm{pH}$ was varied from 2 to 12, the result obtained is shown in Fig. 7. The result shown that at low $\mathrm{pH}$ (strong acidic $\mathrm{pH}$ ), the amount of dye adsorbed was negatively affected. This may be explained by the electrostatic repulsion force generated between the positive surface charge of $\mathrm{CC}$ $\left(\mathrm{pH}<\mathrm{pH}_{\mathrm{PZC}}=5.8\right)$ and the cationic dye (CV). The same results was obtained in a later study, when we have used

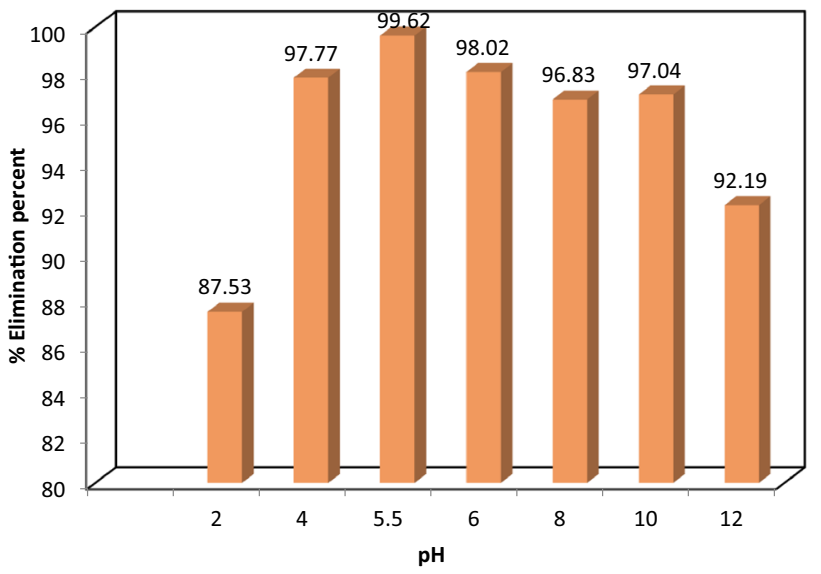

Fig. 7 Effect of solution $\mathrm{pH}$ on the dye removal by $\mathrm{CC}(\mathrm{m}=2.5 \mathrm{~g}$, $\mathrm{W}=300 \mathrm{rpm}, \mathrm{T}=298 \mathrm{~K}$ )

the same adsorbent, cedar cone, for elimination of cationic dye Rhodamine $\mathrm{B}$ from aqueous solution. The adsorption was minimal at low $\mathrm{pH}$, since the electrostatic repulsive force created between the positive surface charge of CC and cationic dye [24].

In the $\mathrm{pH}$ range between 2 and 5.5 ( 5.5 is the $\mathrm{pH}$ of $\mathrm{CV}$ solution without modification) the cedar cone surface is steel positively charged $\left(\mathrm{pH}<\mathrm{pH}_{\mathrm{PZC}}\right)$ and the dye is cationic, which should increase the repulsive forces between the adsorbate and the adsorbent and therefore a decrease in the rate of dye elimination. However, we observed an increase in the amount of dye adsorbed from 87.53 to an maximum of 99.62 at $\mathrm{pH}$ of 5.5 , which can maybe due to another phenomenon other than electrostatic forces like chemo-sorption.

Beyond $\mathrm{pH}$ equal to 5.5 , the elimination rate decreases until reach a value of $92.19 \%$ at very basic $\mathrm{pH}(\mathrm{pH}=12)$. This decrease in the dye removal rate is probably due to the increase in repulsive forces between the negatively charged surface of $\mathrm{CC}$, since $\mathrm{pH}>\mathrm{pH}_{\mathrm{PZC}}$, and the cationic dye, trend was found by Brião et al. [25]. In addition, the amount of $\mathrm{H}^{+}$present in the solution decreases as the $\mathrm{pH}$ increases, reducing the competition between them and the dye to occupy active adsorption sites [26]. The optimal $\mathrm{pH}$ given almost a total elimination of dye is the $\mathrm{pH}$ of $\mathrm{CV}$ solution (without modification) which is 5.5 .

\subsection{Isotherm adsorption}

The adsorption isotherms are generally used for the design and determination of the interaction mechanisms existing between the adsorbate and the adsorbent at equilibrium [27]. However, the adsorption isotherms of crystal violet by cedar cones, were studied at temperatures of 298,308 


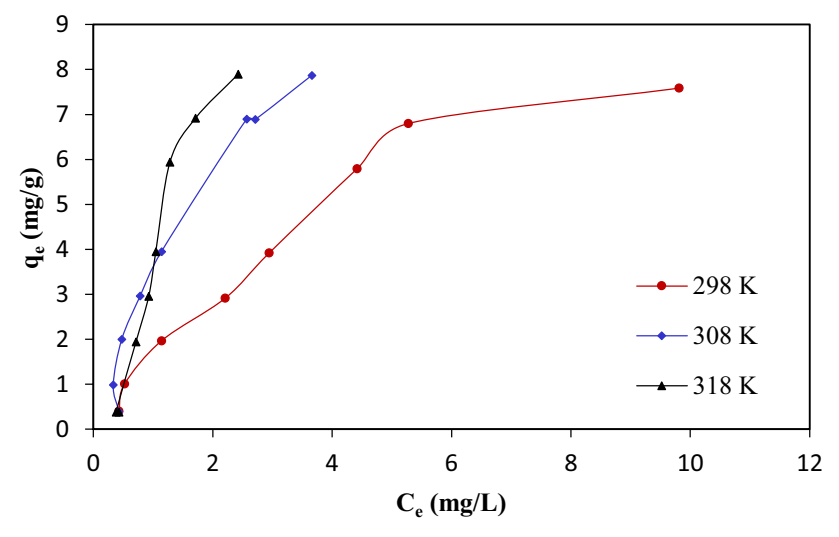

Fig. 8 Isotherms of adsorption of CV by CC at different temperatures 298,308 and $318 \mathrm{~K}$

and $318 \mathrm{~K}$, for different concentrations of dye. The results obtained are illustrated in Fig. 8.

The isotherms obtained show that the variation of $\mathrm{q}_{\mathrm{e}}$ as a function of the equilibrium concentration $C_{e}$ gives a curve of concavity turned down which makes it compatible with the "L-type" isotherm (normal Langmuir) [28]. This result can be explained by the existence of weak lateral interactions [28].

To describe better the adsorption process, the experimental data were fitted using isothermal models of Langmuir and Freundlich. Langmuir isotherm model describe quantitatively the formation of a monolayer adsorbate on the outer surface of the adsorbent, and after that, no further adsorption takes place $[29,30]$. Freundlich isotherm model describes biosorption onto a heterogeneous surface [31]. The mathematical expression of Longmuir and Freundlich are summarizes in Table 2. The model parameters of Langmuir and Freundlich equation were evaluated by non-linear regression method. For the determination of the best fitting isotherm to the experimental data, we consider the value of regression coefficient $\left(R^{2}\right)$, and the sum square error function (SSE) which is represented as follows:

Table 2 Langmuir and Freundlich isotherm parameters obtained by non-linear fitting

\begin{tabular}{lllll}
\hline Type & $\begin{array}{l}\text { Non-linear equa- } \\
\text { tion }\end{array}$ & Parameters & Value & SSE \\
\hline Langmuir & \multirow{2}{*}{$\mathrm{Q}_{\mathrm{e}}=\frac{\mathrm{Q}_{\mathrm{m} \mathrm{K}_{\mathrm{L}}}}{1+\mathrm{K}_{\mathrm{L}} \mathrm{C}_{\mathrm{e}}}$} & $\mathrm{Q}_{\mathrm{m}}(\mathrm{mg} / \mathrm{g})$ & 13.646 & \pm 2.307 \\
& & $\mathrm{~K}_{\mathrm{L}}(\mathrm{L} / \mathrm{mg})$ & $0.146 \pm 0.044$ \\
& & $\mathrm{R}^{2}$ & 0.970 & - \\
\multirow{2}{*}{ Freundlich } & $\mathrm{Q}_{\mathrm{e}}=\mathrm{K}_{\mathrm{F}} \mathrm{C}_{\mathrm{e}}^{1 / \mathrm{n}}$ & $\mathrm{K}_{\mathrm{F}}(\mathrm{mg} / \mathrm{g})(\mathrm{L} /$ & 0.435 & \pm 0.069 \\
& & $\mathrm{mg})^{1 / \mathrm{n}}$ & & \\
& & $\mathrm{n}$ & 0.717 & \pm 0.044 \\
& & $\mathrm{R}^{2}$ & 0.991 & - \\
\hline
\end{tabular}

SN Applied Sciences

A SPRINGER NATURE journal
$\mathrm{SSE}=\sum_{\mathrm{i}=1}^{\mathrm{n}}\left(\mathrm{q}_{\mathrm{e}, \text { calc }}-\mathrm{q}_{\mathrm{e}, \text { meas }}\right)_{\mathrm{i}}^{2}$

where $\mathrm{q}_{\mathrm{e} \text {,meas }}$ is the experimental value, $\mathrm{q}_{\mathrm{e}, \text { calc }}$ is the calculated value, $n$ is the number of data points in the experiment.

The dimensionless equilibrium parameter $R_{L}(4)$ indicates the nature of the shape of the isotherm accordingly $[2,6]$ :

$\mathrm{R}_{\mathrm{L}}=\frac{1}{\left(1+\mathrm{K}_{\mathrm{L}} \mathrm{C}_{0}\right)}$

where $C_{0}$ is the initial concentration of dye $(\mathrm{mg} / \mathrm{L})$, and $\mathrm{K}_{\mathrm{L}}$ $(\mathrm{L} / \mathrm{mg})$ is the Langmuir constant. The $R_{L}$ is used to evaluate the adsorption behavior of adsorbate onto adsorbent, if:

- $\mathrm{R}_{\mathrm{L}}>1$ unfavorable adsorption;

- $0<R_{L}<1$ favorable adsorption;

- $\mathrm{R}_{\mathrm{L}}=0$ irreversible adsorption;

- $\mathrm{R}_{\mathrm{L}}=1$ linear adsorption.

Referring to Figs. 9 and 10 and the results regrouped in Table 2, the coefficient of correlation $\left(r^{2}\right)$ determined by Freundlich model is greater or equal to 0.991 , which show the good linearity and good agreement between the experimental and simulated non-linear fitting curve, with very small value of error function $\left(\approx \pm 69 \times 10^{-2}\right)$.

The coefficient of correlation determined by Langmuir equation (Table 2$)(\geq 0.97)$, show that this model can also fitted the experimental data, but it is feebler than that obtained by Freundlich model. Moreover, the value of error function obtained by non-linear regression of Langmuir is more or less greater $( \pm 2.307)$. This allow us to concluded that the Freundlich model provide best fit to the

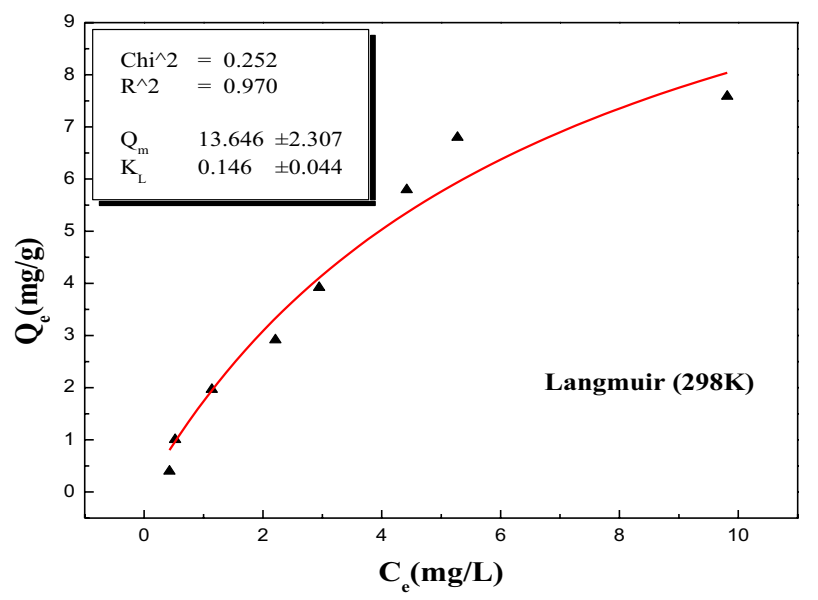

Fig. 9 Non-linear fitting of Langmuir isotherm model for the adsorption of CV by CC 


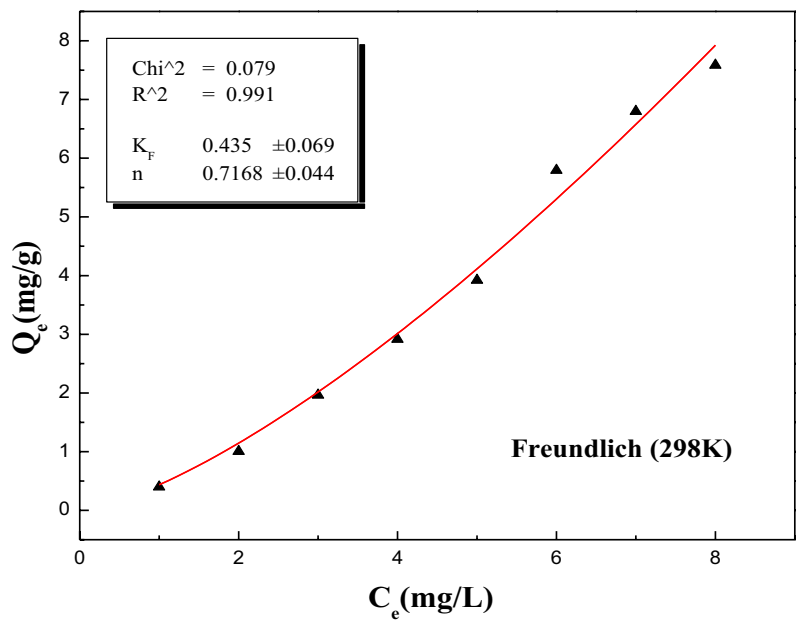

Fig. 10 Non-linear fitting of Freundlich isotherm model for the adsorption of $\mathrm{CV}$ by CC

equilibrium adsorption data compared by the Langmuir one. Similar result was reported in the literature, where the Freundlich model fit more better the experimental data then Langmuir, it's about the study of CV adsorption on magnetic chitosan nanocomposite [32] and the adsorption of CV on waste materials [33].

The $1 / \mathrm{n}$ value $>1$ indicates the favorable adsorption of dye onto adsorbent surface [2]. The value of separation factor $R_{\mathrm{L}}$ calculated at initial concentration of dye of $50 \mathrm{mg} / \mathrm{L}$ is equal to $0.77\left(0<R_{L}<1\right)$, which means that the $\mathrm{CV}$ adsorption onto CC was favorable.

\section{Kinetic of adsorption}

In order to examine the adsorption kinetics of CV on CC, the pseudo-first and pseudo second order model were applied to the kinetic experimental data. The pseudo-first order model, developed by Largergren, is the first rate equation describing the adsorption kinetics of an adsorbent-adsorbent pair. It is based on the amount adsorbed. The adsorption rate at a time $t$ is proportional to the difference between the quantity adsorbed at the equilibrium $\mathrm{q}_{\mathrm{e}}$ and that adsorbed at the instant $\mathrm{t}[34]$ and is represented as:

$\frac{d q}{d t}=K_{1}\left(q_{e}-q_{t}\right)$

with: $\mathrm{K}_{1}$ : Speed constant of pseudo first order ( $\left.1 / \mathrm{min}\right)$.

The integration of the equation for the initial conditions $q_{t}=0$ to $t=0$ gives the Eq. (6):

$\operatorname{Ln}\left(q_{e}-q_{t}\right)=\operatorname{Ln} q_{e}-K_{1} t$

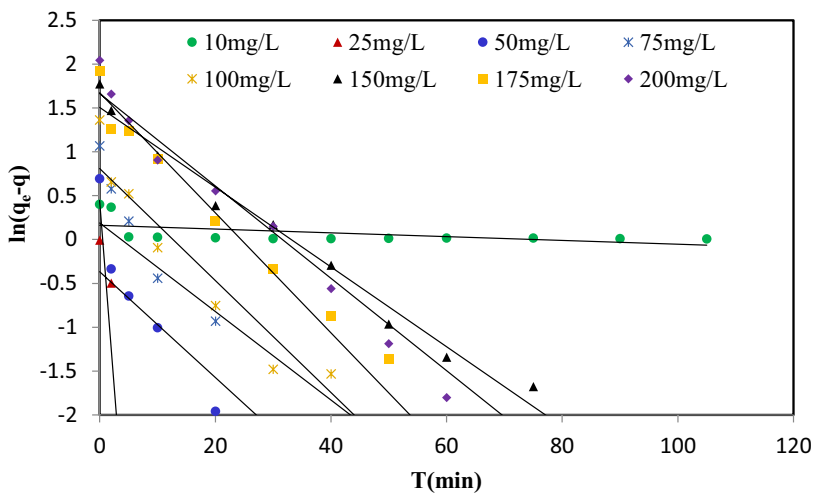

Fig. 11 Plot of the linear form of the pseudo-first-order kinetic model at $\mathrm{T}=298 \mathrm{~K}$

The amount of equilibrium adsorbed solute $\mathrm{q}_{\mathrm{e}}$ and the pseudo-first order rate constant $K_{1}$ are determined experimentally by plotting of $\operatorname{Ln}\left(q_{e}-q_{t}\right)$ versus $t$.

The pseudo-second order adsorption rate established by Blanchard [35] also depends on the amount adsorbed at equilibrium. Is expressed in the form:

$\frac{d q}{d t}=K_{2}\left(q_{e}-q_{t}\right)$

with: $\mathrm{K}_{2}$ : the pseudo second order rate constant $(\mathrm{g} /$ mg.min).

The integration of Eq. (7) with the limiting conditions $\mathrm{q}_{\mathrm{t}}=0$ to $\mathrm{t}=0$ takes the linear form as described by equation:

$\frac{1}{q_{t}}=\frac{1}{k_{2} q_{e}^{2}}+\frac{1}{q_{e}} t$

The plot of $1 / q_{t}$ against $t$ gives a linear relationship for the applicability of the second-order kinetic, with a slope of $1 / \mathrm{q}_{\mathrm{e}}$ and an ordinate at the origin of $\frac{1}{\mathrm{k}_{2} \mathrm{q}_{\mathrm{e}}^{2}}$.

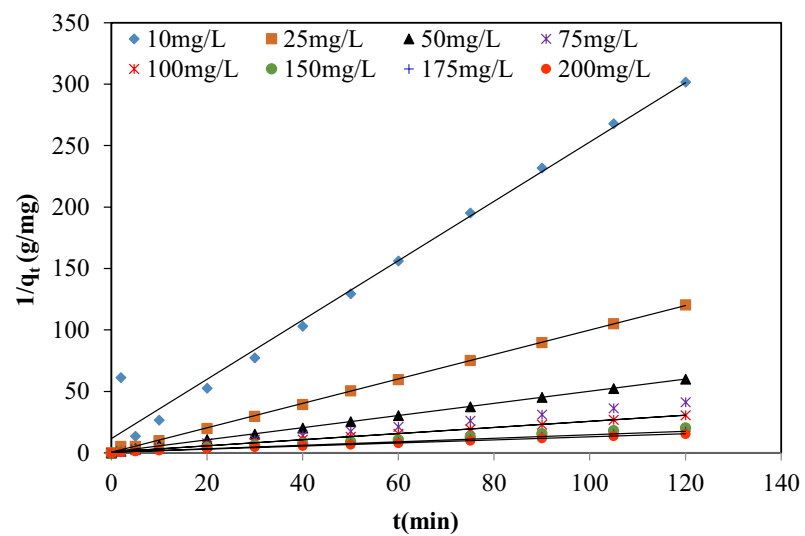

Fig. 12 Plot of the linear form of the pseudo-second-order kinetic model at $\mathrm{T}=298 \mathrm{~K}$ 
Table 3 Values of pseudosecond order adsorption rate constants and correlation coefficients for different initial CV concentrations at $\mathrm{T}=298 \mathrm{~K}$

\begin{tabular}{|c|c|c|c|c|c|c|c|c|}
\hline \multirow[t]{2}{*}{ Model } & \multicolumn{8}{|c|}{ Initial dye concentration (mg/L) } \\
\hline & 10 & 25 & 50 & 75 & 100 & 150 & 175 & 200 \\
\hline \multicolumn{9}{|l|}{ Pseudo-first order } \\
\hline $\mathrm{K}_{1}(1 / \mathrm{min})$ & 0.027 & 0.848 & 0.060 & 0.050 & 0.063 & 0.045 & 0.068 & 0.052 \\
\hline $\mathrm{q}_{\text {ethéor }}(\mathrm{mg} / \mathrm{g})$ & 0.07 & 1.558 & 0.692 & 1.209 & 2.250 & 4.512 & 5.340 & 5.275 \\
\hline $\mathrm{q}_{\text {eexp }}(\mathrm{mg} / \mathrm{g})$ & 0.39 & 0.99 & 2.0 & 2.9 & 3.9 & 5.89 & 6.82 & 7.71 \\
\hline$R^{2}$ & 0.48 & 0.91 & 0.92 & 0.91 & 0.96 & 0.98 & 0.98 & 0.98 \\
\hline \multicolumn{9}{|c|}{ Pseudo-second order } \\
\hline $\mathrm{K}_{2}(\mathrm{~g} / \mathrm{mg} \min )$ & 0.39 & 1.78 & 0.29 & 0.13 & 0.07 & 0.02 & 0.036 & 0.027 \\
\hline$q_{\text {ethéo }}(\mathrm{mg} / \mathrm{g})$ & 0.41 & 1.01 & 2.02 & 2.97 & 4.00 & 6.19 & 7.08 & 8.04 \\
\hline$q_{\text {eexp }}(\mathrm{mg} / \mathrm{g})$ & 0.39 & 0.99 & 2.00 & 2.91 & 3.9 & 5.89 & 6.83 & 7.77 \\
\hline $\mathrm{R}^{2}$ & 0.97 & 0.99 & 0.99 & 0.99 & 0.99 & 0.99 & 0.99 & 0.99 \\
\hline
\end{tabular}

The modeling of the adsorption kinetics of $\mathrm{CV}$ by CC by Lagergren and Blanchard equations for different adsorbate concentrations are presented in Figs. 11 and 12. The pseudo-first and second-order rate constants $\mathrm{K}_{1}, \mathrm{~K}_{2}$, the predicted $\mathrm{q}_{\mathrm{e}}$ values, and the corresponding correlation coefficients $R^{2}$ were given in Table 3 .

According to the results of Table 3 , for the kinetic model of pseudo first order, the correlation coefficients $R^{2}$ are acceptable they are greater than 0.90 with an exception at the concentration of $10 \mathrm{mg} / \mathrm{L}\left(\mathrm{R}^{2}=0.48\right)$, and the theoretical adsorption capacity is much lower than that obtained experimentally. This is suggests the not applicability of Lagergren model.

The adsorption kinetics can be analyzed by the Blanchard expression. The plot of $1 / q_{t}$ as a function of time $t$ gives a linear curve. Based on the correlation coefficients of the Blanchard equation (almost equal to 1) and the values of theoretical maximum adsorption capacities which are comparable with the experimental values. This allows us to say that the kinetic adsorptions of CV by CC are pseudo-second-order model.

\section{Conclusion}

The present work shows that cedar cone, an agriculture waste, abundantly available in north Algeria, is an efficient adsorbent for the removal of crystal violet from aqueous solution. The adsorption operating parameters were optimized, the maximum elimination of dye $99.62 \%$, was attained at $\mathrm{pH}$ 5.5, $2.5 \mathrm{~g}$ adsorbent dose, CV initial concentration $50 \mathrm{mg} / \mathrm{L}$ and solution temperature of $298 \mathrm{~K}$. Adsorption isotherms of crystal violet by cedar cones obtained at 298, 308 and $318 \mathrm{~K}$ were of the L-type (Langmuir). The equilibrium data have been analyzed by Langmuir and Freundlich isotherm, using non-linear regression method. The Freundlich model was the most suitable for the adsorption of dye on the cedar cone, with highest coefficient correlation (0.991) and minimum sum square error $\left(\mathrm{SSE}= \pm 69 \times 10^{-2}\right)$. The value of $(1 / \mathrm{n})>1$ indicate that the adsorption is favorable, that was also confirmed by the value of $R_{L}(0>0.77>1)$, which belongs to the field range of favorable adsorption. The adsorption kinetics of $\mathrm{CV}$ onto the CC is well described by the pseudo-second order model.

The CC used in this study, do not necessitate an additional pretreatment such as activation before applications of adsorption possess to give a high capacity for CV. Therefore, the adsorbent is estimated to be economically feasible for removal of $\mathrm{CV}$ dye from aqueous solutions.

Acknowledgements I would like to thank Professor BENCHEIKH LEHOCINE Mossaab for this invaluable advice, scientific skills, encouragement and support. Many thanks are due to the international scientific committee of the second International Symposium (WREIANA 2019) of (Water Resources and Environmental Impact Assessment in North Africa) for the selection of this paper to be submitted for consideration in the volume consisting of selected papers based on oral presentations from the scientific meeting. This paper has been selected from the 2 nd International Symposium on Water Resources and Environmental Impact Assessment in North Africa (WREIANA), March 25-27, 2019 Sousse - Tunisia 2019.

\section{Compliance with ethical standards}

Conflict of interest The authors declare that they have no conflict of interest.

\section{References}

1. Ben Mansour H, Boughzala O, Dridi D, Barillier D, Chekir-Ghedira L, Mosrati (2011) Les colorants textiles sources de contamination de l'eau : CRIBLAGE de la toxicité et des méthodes de traitement. Rev Sci l'eau J Water Sci 24(3):209-238

2. Shukat S, Bhatti HN, lqbal M, Noreen S (2017) Mango stone biocomposite preparation and application for crystal violet adsorption: a mechanistic study. Microporous Mesoporous Mater 239:180-189

3. Guz L, Curutchet G, Torres Sánchez RM, Candal R (2014) Adsorption of crystal violet on montmorillonite (or iron modified montmorillonite) followed by degradation through Fenton or photoFenton type reactions. J Environ Chem Eng 2:2344-2351 
4. Jayasantha Kumari H, Krishnamoorthy P, Arumugam TK, Radhakrishnan S, Vasudevan D (2017) An efficient removal of crystal violet dye from waste water by adsorption onto TLAC/Chitosan composite: a novel low cost adsorbent. Int J Biol Macromol S0141-8130(16):32029-3

5. Fabryanty R, Valenciaa C, Soetaredjo FE, Putro JN, Santoso SP, Kurniawan A, Ju Y-H, Ismadji S (2017) Elimination of crystal violet dye by adsorption using a bentonite-alginate composite. J Environ Chem Eng 5:5677-5687

6. Hameed BH, Mahmoud DK, Ahmad AL (2008) Sorption equilibrium and kinetics of basic dye from aqueous solution using banana stalk waste. J Hazard Mater 158:499-506

7. Bertolini TCR, Izidoro JC, Magdalena CP, Fungaro DA (2013) Adsorption of crystal violet dye from aqueous solution onto zeolites from coal fly and bottom ashes. Electron J Chem 5(3):179-191

8. Marcel LECOMTE, Fiche technique du Crystal violet. https:// www.pdffactory.com

9. Chakraborty S, Chowdhury S, Saha PD (2011) Adsorption of crystal violet from aqueous solution onto $\mathrm{NaOH}$-modified rice husk. Carbohyd Polym 86:1533-1541

10. Miyah $Y$ et al (2017) Assessment of adsorption kinetics for removal potential of crystal violet dye from aqueous solutions using Moroccan pyrophyllite. J Assoc Arab Univ Basic Appl Sci 23:20-28

11. Pare B, Singh P, Jonnalgadda SB (2009) Artificial light assisted photocatalytic degradation of lissamine fast yellow dye in $\mathrm{ZnO}$ suspension in a slurry batch reactor. Indian J Chem 48A:1364-1369

12. Singh P, Raizada P, Pathania D, Sharma G, Sharma P (2013) Microwave induced $\mathrm{KOH}$ activation of guava peel carbon as an adsorbent for congo red dye removal from aqueous phase. Indian J Chem Technol 20:305-311

13. Miyah $Y$, Lahrichi A, Idrissi $M$, Boujraf $S$, Taouda $H$, Zerrouq $F$ (2017) Assessment of adsorption kinetics for removal potential of crystal violet dye from aqueous solutions using Moroccan pyrophyllite. J Assoc Arab Univ Basic Appl Sci 23:20-28

14. Patil S, Deshmukh V, Renukdas S, Patel N (2011) Kinetics of adsorption of crystal violet from aqueous solutions using different natural materials. Int J Environ Sci 1:6

15. Lairini S, El Mahtal K, Miyah Y, Tanji K, Guissi S, Boumchita S, Zerrouq $F$ (2017) The adsorption of crystal violet from aqueous solution by using potato peels (Solanum tuberosum): equilibrium and kinetic studies. JMES 8(9):3252-3261

16. Idrissi N, Lairini S, Nenov V, Zerrouq F (2017) Removal of cationic dye "Crystal Violet" in aqueous solution by the local clay. JMES 8(10):3570-3582

17. Nandi BK, Goswami A, Das AK, Mondal B, Purkait MK (2008) Kinetic and equilibrium studies on the adsorption of crystal violet dye using Kaolin as an adsorbent. Sep Sci Technol 43:1382-1403

18. Cheruiyot GK, Wanyonyi WC, Kiplimo JJ, Maina EN (2019) Adsorption of toxic crystal violet dye using coffee husks: equilibrium, kinetics and thermodynamics study. Sci Afr 5:e00116

19. Sarma GK, Gupta SS, Bhattacharyya KG (2016) Adsorption of Crystal violet on raw and acid-treated montmorillonite, $\mathrm{K} 10$, in aqueous suspension. J Environ Manag 171:1-10

20. Patel J (2017) Analyses of densely crosslinked phenolic systems using low field NMR. Doctoral Dissertations, 1116
21. Patel JP, Deshmukh S, Zhao C, Wamuo O, Hsu SL, Schoch AB, Carleen SA, Matsumoto D (2016) An analysis of the role of nonreactive plasticizers in the crosslinking reactions of a rigid resin. J Polym Sci Part B Polym Phys 55:206-213

22. Patel JP, Xiang ZG, Hsu SL, Schoch AB, Carleen SA, Matsumoto D (2015) Path to achieving molecular dispersion in a dense reactive mixture. J Polym Sci Part B Polym Phys 53:1519-1526

23. Banerjee $S$, Chattopadhyaya MC (2017) Adsorption characteristics for the removal of a toxic dye, tartrazine from aqueous solutions by a low cost agricultural by-product. Arab J Chem 10(2):S1629-S1638

24. Zamouche $M$, Hamdaoui O (2012) Sorption of Rhodamine B by cedar cone: effect of $\mathrm{pH}$ and ionic strength. Energy Procedia 18:1228-1239

25. Brião GV, Jahn SL, Foletto EL, Dotto GL (2017) Adsorption of crystal violet dye onto a mesoporous ZSM- 5 zeolite synthetized using chitin as template. Colloid Interface Sci 508:313-322

26. Miyah $Y$ et al (2017) Removal of cationic dye "crystal violet" in aqueous solution by the local clay. JMES 8(10):3570-3582

27. Crini G, Lichtfouse E, Wilson LD, Morin-Crini N (2018) Adsorptionoriented processes using conventional and non-conventional adsorbents for wastewater treatment. In: Crini G, Lichtfouse E (eds) Green adsorbents for pollutant removal. Environmental chemistry for a sustainable world, vol 18. Springer, Cham, pp 23-71. https://doi.org/10.1007/978-3-319-92111-2_2

28. Giles CH, Mac Ewan TH, Nakhwa SN, Smith D (1960) A system of classification of solution adsorption isotherms, and its use diagnosis of adsorption mechanisms and in measurements of specific surface areas of solids. Studies in adsorption. Part XI. J Chem Soc 10:3973-3993

29. Dada AO, Olalekan AP, Olatunya AM, Dada O (2012) Langmuir, Freundlich, Temkin and Dubinin-Radushkevich isotherms studies of equilibrium sorption of $\mathrm{Zn}^{2+}$ unto phosphoric acid modified rice husk. IOSR J Appl Chem 3(1):38-45

30. Langmuir I (1916) The constitution and fundamental properties of solids and liquids. J Am Chem Soc 38:2221-2295

31. Freundlich HMF (1906) Über die adsorption in lösungen. Z Phys Chem 57A:385-470

32. Massoudinejad M, Rasoulzadeh H, Ghaderpoori M (2019) Magnetic Chitosan nanocomposite: fabrication, properties, and optimization for adsorptive removal of crystal violet from aqueous solutions. Carbohyd Polym 206:844-853

33. Mittal A, Mittal J, Malviya A, Kaur D, Gupta VK (2010) Adsorption of hazardous dye crystal violet from wastewater by waste materials. J Colloid Interface Sci 343:463-473

34. Jianlong W, Xinmin Z, Decai D, Ding Z (2001) Bioadsorption of lead(II) from aqueous solution by fungal biomass of Aspergillus niger. J Biotechnol 87:273

35. Blanchard G, Maunaye M, Martin G (1984) Removal of heavy metals from waters by means of natural zeolites. Water Res 18:1501-1507

Publisher's Note Springer Nature remains neutral with regard to jurisdictional claims in published maps and institutional affiliations. 